\title{
Giant Sweetpotato Bug, Spartocera batatas (Fabricius) (Insecta: Hemiptera: Coreidae) ${ }^{1}$
}

Susan E. Halbert ${ }^{2}$

\section{Introduction}

A large colony of Spartocera batatas (Fabricius) was found in late June 1995 on an Asian cultivar of sweet potatoes (Ipomoea batatas) in Homestead, Florida, by Lynn D. Howerton, environmental specialist, Division of Plant Industry (DPI). The plants were badly damaged by the insects. That collection represented the first report of S. batatas in the continental U.S. Subsequent surveys of commercial fields of sweet potatoes in the area failed to turn up any more $S$. batatas. However, an additional single specimen was found in Miami in early October 1995 by DPI Inspector Ramon A. Dones. Many bugs were found in suburban Miami by Julieta Brambila (University of Florida, Institute of Food and Agricultural Sciences) in late September 1996.

\section{Distribution}

Spartocera batatas was described from Surinam and is also found on several of the Caribbean islands. It is considered a minor pest of sweet potatoes in Puerto Rico (A. Pantoja, University of Puerto Rico,

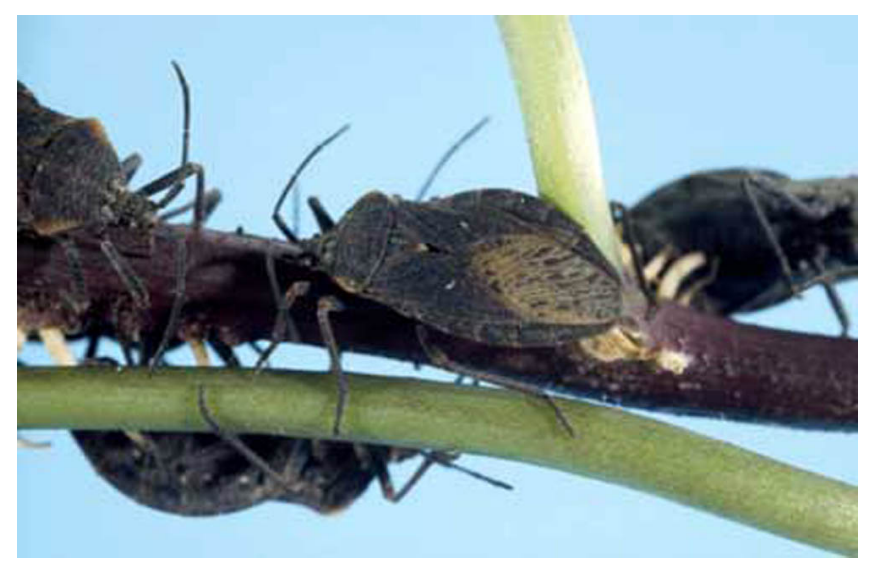

Figure 1. Colony of Spartocera batatas (Fabricius), a sweet potato pest, on sweet potato. Credits: Photograph by: Jeffrey Lotz, DPI, FDACS

personal communication). Records from Cuba indicate apparent range expansion across the island (Ravelo 1988). It is not known when or how the insect was introduced into Florida, but its limited distribution suggests that the introduction was recent at that time.

\footnotetext{
1. This document is EENY-305 (originally published as DPI Entomology Circular 379), one of a series of Featured Creatures from the Entomology and Nematology Department, Florida Cooperative Extension Service, Institute of Food and Agricultural Sciences, University of Florida. Published: October 2003. This document is also available on Featured Creatures Website at http://creatures.ifas.ufl.edu. Please visit the EDIS Website at http://edis.ifas.ufl.edu. Additional information on these organisms, including many color photographs, is available at the Entomology and Nematology Department website at http://entnemdept.ifas.ufl.edu/.

2. Susan E. Halbert, Florida Department of Agriculture and Consumer Services, Division of Plant Industry, Gainesville, FL.
}

The Institute of Food and Agricultural Sciences (IFAS) is an Equal Employment Opportunity - Affirmative Action Employer authorized to provide research, educational information and other services only to individuals and institutions that function without regard to race, creed, color, religion, age, disability, sex, sexual orientation, marital status, national origin, political opinions or affiliations. For information on obtaining other extension publications, contact your county Cooperative Extension Service office. Florida Cooperative Extension Service / Institute of Food and Agricultural Sciences / University of Florida / Larry R. Arrington, Interim Dean 


\section{Description}

Spartocera batatas belongs to the tribe Spartocerini (=Corecorini of Baranowski and Slater (1986) and Blatchley (1926)) (Froeschner 1988). Characteristics of the tribe include absence of spines and leaf-like dilations on the legs and antennae (including antennal tubercles), short mouthparts (not extending past the midcoxae) and square head with a deep groove between the antennal sockets. Within the Spartocerini, the genus Spartocera (=Corecoris) can be recognized by the irregular anastomosing veins on the membranes of the forewings and by the absence of lateral toothlike projections on the pronotum (Alayo 1967, Baranowski and Slater 1986).

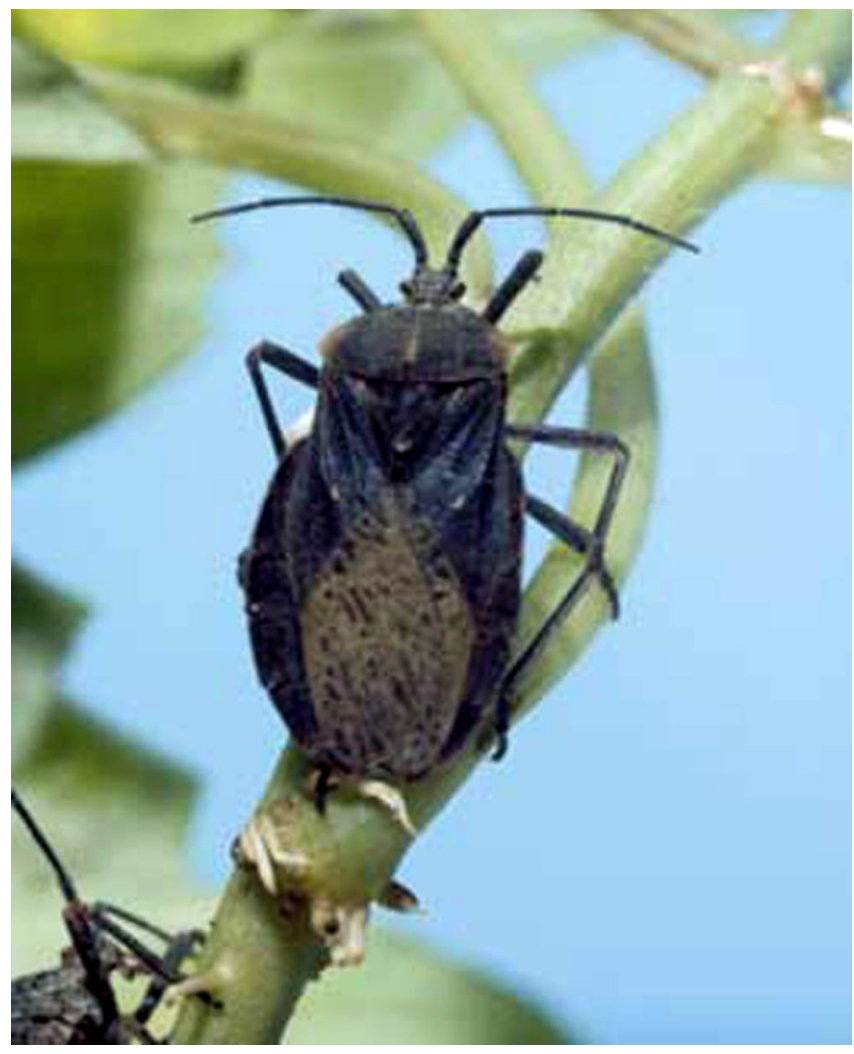

Figure 2. Adult Spartocera batatas (Fabricius), a sweet potato pest. Credits: Photograph by: Jeffrey Lotz, DPI, FDACS

Adult $S$. batatas are large insects, 18 to $23 \mathrm{~mm}$ in length. They are entirely dark brown. Lateral (humeral) angles of the pronotum are rounded and without teeth, and the lateral margins of the pronotum are not expanded. Newborn nymphs are red. They soon lose their bright color and become very dark brown except for the head, the lateral angles of the pronotum and the expanded lateral edges of the abdomen, which are marked with bright red-brown spots. Eggs are shaped like tiny fat sausages, and their color varies from gold to brown with age.

\section{Key to Florida Species of Spartocera}

Key is based on Alayo 1967, Baranowski and Slater 1986, Blatchley 1926 and specimens at the Florida State Collection of Arthropods.

1. Antennae short, joints II and III subequal, IV $1 / 3$ shorter, antennal joint I scarcely longer than the head, rare in Florida, biology unknown . . . . S. diffusus

1'. Antennae longer, joints II to IV subequal, antennal joint I obviously longer than the head . . . . . 2

2. Bright orange or yellow insect, pronotum with a pair of black longitudinal lines, on Solanum americanum ..... S. fuscus

2'. Uniformly dark brown insect, pronotum without markings, on sweet potato and a few other plants (see host list below) ..... S. batatas

\section{Hosts}

The most important host of $S$. batatas appears to be sweet potato, after which it was named. Other hosts listed in the literature include Solanaceae [tomato (Lycopersicon esculentum), eggplant (Solanum melongena var. esculentum), potato (Solanum tuberosum), and Solanum nigrum], Lauraceae [avocado (Persea americana)] and Rutaceae (Citrus spp.) (Ravelo 1988, Martorell 1976, Alayo 1967, Barber 1939, Wolcott 1923).

Observations in Florida indicate that $S$. batatas adults sometimes disperse in high numbers. Thus, transient adults could be collected on a wide variety of plants. It is not known which of the above host records represent breeding populations.

\section{Pest Status}

The pest potential of $S$. batatas in Florida is currently unknown. It is unlikely that it will prove to be a serious pest. Other than the single article from Cuba (Ravelo 1988), there is no recent literature 
concerning the economics of $S$. batatas. In Puerto Rico, $S$. batatas is abundant, but is not considered to be a major pest, even on sweet potato. Although $S$. batatas is reported from citrus, there are no reports of damage.

Spartocera batatas was found in Florida on an Asian cultivar of sweet potato that is grown for its tender shoot tips rather than for tubers. The damage to those plants was severe, indicating that some sweet potato varieties may be susceptible to serious injury. However, the fact that nearby commercial fields of sweet potatoes were not infested suggests that damage may depend strongly on plant variety. Spartocera batatas was found in home garden situations. It remains to be seen whether $S$. batatas will become a pest in commercial fields.

Spartocera batatas is a very large obvious bug with a nasty odor. Thus, whether or not it becomes a significant pest in commercial settings, it is likely that specimens will be collected and sent in by home owners and commercial growers.

\section{Management}

Based on experience controlling squash bugs on pumpkin and winter squash, adult $S$. batatas may be very difficult to control with insecticide. Thus, adequate control may depend on timing of application so that young nymphs are exposed to the insecticide. Efficacy data on specific materials are not currently available.

For more management information see: Insect Management Guide for Potatoes (http://edis.ifas.ufl. edu/IG155)

Insect Management Guide for Tomatoes, Peppers and Eggplant (http://edis.ifas.ufl.edu/IN169)

\section{Selected References}

Alayo PD. 1967. Los hemipteros cubanos de la familia Coreidae. Catalogo de la Fauna de Cuba XXV. Los Hemipteros de Cuba VIII. Trabajos de Divulgación No. 56. Museo "Felipe Poey" de la Academia de Ciencias de Cuba. 41 p.

Barber HG. 1939. Scientific Survey of Puerto Rio and the Virgin Islands. Volume 14, Part 3.
Hemiptera-Heteroptera (excepting the Miridae and Corixidae). New York Academy of Sciences, New York, NY. 441 p.

Baranowski RM, Slater JA. 1986. Coreidae of Florida (Hemiptera: Heteroptera). Arthropods of Florida and Neighboring Land Areas. Florida Department of Agriculture and Consumer Services, Gainesville, FL. Volume 122. 82 p.

Blatchley WS. 1926. Heteroptera or True Bugs of Eastern North America. Nature Publishing Company, Indianapolis. $1116 \mathrm{p}$.

Froeschner RC. 1988. Family Coreidae Leach, 1815. pp. 69-92. In Henry TJ, Froeshner RC. (eds.), Catalog of the Heteroptera, or True Bugs, of Canada and the Continental United States. E.J. Brill, Leiden, New York, Kobenhavn, Koln.

Martorell LF. 1976. Annotated Food Plant Catalog of the Insects of Puerto Rico. University of Puerto Rico Agricultural Experiment Station. 276 p.

Ravelo HG. 1988. Spartocera batatas (Fabricius) (Heteroptera: Coreidae) en Cuba. Centro Agricola 15: 87-88.

Wolcott GN. 1923. "Insectae Portoricensis" A preliminary annotated check-list of the insects of Porto Rico, with descriptions of some new species. Journal of the Department of Agriculture of Porto Rico 7: 5-311. 